\title{
The importance of swap transactions in the evolution of the Polish currency market and the OTC interest rate derivatives market
}

\author{
Robert W. Włodarczyk, Magdalena Sikorska
}

\begin{tabular}{|c|c|c|}
\hline \multicolumn{3}{|c|}{ A B STR ACT } \\
\hline \multicolumn{3}{|c|}{$\begin{array}{l}\text { Objective: The article aims to present the importance of swap transactions in the evo- } \\
\text { lution of the Polish currency market and the OTC interest rate derivatives market. }\end{array}$} \\
\hline \multicolumn{3}{|c|}{$\begin{array}{l}\text { Research Design \& Methods: The theoretical considerations in the article were based on } \\
\text { a critical analysis of the literature on the subject. In turn, the empirical part of this article } \\
\text { was developed using numerical parameters characterizing the studied phenomenon. }\end{array}$} \\
\hline \multicolumn{3}{|c|}{$\begin{array}{l}\text { Findings: It cannot be unequivocally confirmed that swaps, due to their universality anc } \\
\text { design, are the most frequently used instrument of the Polish currency market and the } \\
\text { OTC interest rate derivatives market. This is because, although, on the currency market, the } \\
\text { main share in transactions was achieved by currency swaps, in the case of the OTC interest } \\
\text { rate market, interest rate swap (IRS) transactions no longer record the largest share. }\end{array}$} \\
\hline \multicolumn{3}{|c|}{$\begin{array}{l}\text { Contribution \& Value Added: The issue of swap contracts, according to the authors of } \\
\text { the thesis, is the subject of limited interest in the Polish research literature, and this } \\
\text { article was to be a response to the need to systematize knowledge about these instru- } \\
\text { ments and a synthetic presentation of their development. }\end{array}$} \\
\hline Article type: & research paper & \\
\hline Keywords: & Nap; currency m & \\
\hline JEL codes: & G130, G190, G320 & \\
\hline & d: 16 October 2019 & Article accepted: 15 December 2019 \\
\hline
\end{tabular}

\section{Suggested citation:}

Włodarczyk, R.W., \& Sikorska, M. (2019). The importance of swap transactions in the evolution of the Polish currency market and the OTC interest rate derivatives market. International Entrepreneurship Review (previously published as International Entrepreneurship / Przedsiębiorczość Międzynarodowa), 5(4), 109-122. https://doi.org/10.15678/IER.2019.0504.07

\section{INTRODUCTION}

Swap transactions have been in the spotlight for several decades. They are the subject of discussions between practitioners, investors, as well as representatives of science. J. Hull (1998) emphasizes, that the first swap transactions in the world were concluded in 1981. 
So, these are relatively "young" financial instruments that have entered the financial markets quite aggressively. Varied use of swap contracts is possible due to the existence of numerous variations as well as availability on the OTC market (Kukurba, 2016). In the practice of business operations, swap contracts are treated as a tool to support the proper management of their assets and liabilities. They also allow modifying currency, interest, and risk of changes in the prices of shares and commodities. As financial markets became uncertain and risky, measuring and managing the risks of participants in the financial markets became the main focus of modern finance theory (Martinkutè-Kaulienè, 2015). In the period of globalization of financial markets, which is part of the broader phenomenon of globalization of national economies, swap contracts enable effective optimization of capital use in terms of quantity, costs and affect the diversification of cash flows. Currently, swap contracts are an inseparable element of international finance. We find them in most domestic and international money and capital markets.

The article aims to present the importance of swap transactions in the evolution of the Polish currency market and the OTC interest rate derivatives market. The authors of the article sought the answer to the question of whether swaps, due to their universality and design, are the most frequently used instrument of the Polish currency market and the OTC interest rate derivatives market.

The next part of the study presents a review of the literature on the theoretical aspects of the currency market and the OTC interest rate derivatives market, as well as swap contracts. Definitions and theories regarding these markets have been presented. Their features, operating principles, and the most important participants were characterized. The next chapter presents the general meaning of swap contracts - their definitions, types, and meaning have been described. The fourth chapter contains the results of the analysis regarding the share of swap transactions in the development of the Polish currency market and the OTC interest rate derivatives market in the years 2004-2016. The source of empirical data is the results of the turnover study on the foreign exchange market and the OTC derivatives market in Poland. The dynamics of changes and the share of swap contracts in all transactions on selected financial markets were examined. The last chapter is the ending and contains a summary of the analyzes carried out and a commentary on the presented conclusions.

\section{LITERATURE REVIEW}

\section{Currency and interest rate swaps: definitions and classifications}

Swap transactions belong to a broader group of assets called derivatives. They are a component of the derivatives market, where in addition to swap contracts there are also forward transactions, futures contracts, and options. The value of derivatives, including swap contracts, depends on the value of other assets to which they were issued. These assets are referred to in the literature as basic, primary or underlying instruments (Czekaj, 2008). However, it should be noted that there is a relatively frequent problem separating the derivative market from other financial market segments. This is because, in practice the basic instruments are both capital, money and currency market instruments, as well, as stock market indices or interest rates (Kolb, 1997). As a result, derivatives are included in the capital, money, currency and commodity markets, depending on the nature of the assets that are underlying assets in these instruments. It is similar 
with swap transactions, which on the one hand, are a derivative instrument, on the other hand, can be classified into different financial market segments.

The literature on the subject contains many divisions of derivatives. The classification of derivatives by necessary instruments deserves special attention (Jajuga, 2009):

- derivative instruments on shares (also known as equity derivative instruments) the primary instrument is the company's share and, above all, its price,

- foreign exchange derivative (also known as currency derivatives) - the underlying instrument is a currency, more precisely the exchange rate,

- derivatives on stock market indices (otherwise referred to as index derivatives) the primary instrument is the stock index, usually the stock exchange index,

- interest rate derivatives - the basic instrument is the interest rate from the financial market or a debt instrument such as a bond or treasury bill.

In the empirical part of this thesis, mainly instruments from the interest rate derivatives market, and more specifically, interest rate swaps (IRS transactions) and the currency derivatives market will be discussed.

The term swap used in Polish literature comes from English and is understood as an exchange process. Swaps are agreements between two parties to exchange one series of future cash flows for another (Martinkutè-Kaulienè, 2015). This process is also mediated by another financial institution called a swap dealer. The exchange of payments is created in such a way that both parties of the contract and the intermediary financial institution gain a sure profit. In practice, this is possible if the difference in interest rate proposed to the transaction parties is positive. Also, attention should be paid to relevant information that is specified in the swap contract and applies to, i.e., (Marynarski, 1999):

- payment currency,

- transaction prices,

- maturity date,

- the time of commencement and frequency of payments.

Swaps belong to the category of symmetrical financial instruments related to the obligation to conclude transaction agreements, the subject of which is the underlying instrument on the terms and within the time limit arising from the parameters of the derivative (NBP, 2018). In practice, this means that one of the participants of the transaction must buy a fixed amount of the underlying on the day of the transaction, and the other of the participants of the transaction is required to sell the same amount of the underlying instrument. Formally, this transaction may be related to the physical delivery of the underlying instrument, e.g., a barrel of oil, or making a cash equivalent payment, determined on the basis of the difference between the value of the underlying instrument on the transaction maturity date and the transaction price resulting from the parameters of the derivative (Trader's area, 2018).

In other terms, a swap is defined as a portfolio of forward contracts. It combines a long position in one bond with a short position in the other bond. It is also called a "tailormade" contract because the parties to the transaction can create an entirely new contract that satisfies their needs much better than other standard financial instruments. The parties to the contract determine the most convenient contract expiration date themselves 
and set the amount they exchange as part of the transaction and are not limited by fixed contractual conditions, as in the case of instruments listed on the stock exchange.

The Bank for International Settlements (BIS) is involved in the study of swap transactions, especially on the OTC market. Since 2010, BIS has proposed a new classification of transactions, according to which the following instruments are distinguished within the currency market:

- spot transactions,

- outright forward transactions (including transactions with differential settlement),

- currency swaps,

- CIRS transactions,

- currency options.

In turn, BIS qualified for transactions related to the OTC interest rate market:

- forward rate agreement (FRA),

- interest rate options,

- one-currency interest rate swaps (IRS).

Swap contracts, due to their versatility and design, can create very different forms, often similar to other financial instruments. However, in the practice of the functioning of the financial market, swaps are distinguished by their flexibility and uniqueness. The following typology of swaps is most common in the literature on the subject (Malinowski, 2011):

- plain vanilla swaps - which form the first-generation swaps, including currency, interest rate, and currency-interest rate swaps,

- swap derivatives - which form second-generation swaps, are a modification of classic swaps as well as other derivatives.

A separate group of derivatives - linked to interest rate instruments - are credit derivatives or credit risk swaps (CRS). They allow to isolate credit risk from other types of risk existing on the financial market as well as to manage and trade this risk (Rule, 2011).

\section{Reasons for development and operation mechanism of swap contracts}

The use of derivatives on a larger scale began in many international markets in the 1970s and continues to this day. Contributing to this was the progressive increase in interest rates, exchange rate volatility, and stock and commodity prices. Not without reason was the rise in debt of many countries and increased risk in financial and commodity markets, as well as the acceleration of the frequency of economic fluctuations and shortening the period of business cycles. The changes could be observed in global markets, and the increase in the volatility of prices of financial instruments resulted in a higher risk of investing in these instruments. Derivatives were therefore introduced to limit the risk. Derivatives are futures, which means that the buyer (seller) of the goods guarantees the purchase (sale) of these goods in the future at predetermined prices. Conditions favoring the development of the derivatives market occur when the cost of necessary instruments shows fluctuations, which in turn generate the risk of changes in these prices. Another factor is the gradual process of globalization of the economy, and with it, the development of international trade and other connections with foreign entities, which increases the risk of changes in the value of both assets and liabilities of economic entities expressed in foreign currency (Czekaj, 2008). Under the influence of these changes, commodity derivatives also developed, whose main task was to limit 
the risk of changes in commodity prices, and more specifically to hedge against the appreciation or depreciation of commodity prices, primarily agricultural products (Jajuga, 2009). However, it should be remembered that regardless of the form of derivatives used, it is impossible to estimate all future changes with a hundred percent accuracy. It is imperative to know and identify the risks that may occur. Besides, the use of derivatives in financial markets requires excellent skills and extensive experience.

An essential part of the development of the derivatives market are changes occurring within swap transactions. The cooperation of the Bank for International Settlements with central banks and taking actions in the scope of regulating the functioning of the swap market show that its growing importance and problems related to its functioning are being recognized (Kukurba, 2016). The development of swap transactions was a direct result of the change in financial market conditions and the related increase in the risk of entities' operations in the 1970s. The importance of the swap market has also increased due to the creation process and the rather rapid development of global currency markets. Foreign exchange swaps were the first type of convertible operations. They were the result of the introduction by the United Kingdom of foreign exchange restrictions in the form of an unfavorable exchange rate when purchasing foreign currencies for foreign investment, as well as a ban on granting loans in pounds to finance foreign trade, aimed at counteracting speculative attacks on the pound (Tymuła, 2000). Swap transactions are currently an essential part of the financial market, including the currency market and the derivatives market. A.M. Chisholm (2009) rightly emphasizes that swaps are one of the most important tools of modern financial markets. Swap contracts are an inseparable element of international finance. They are used in most areas of the country and international money and capital markets (McDougall, 2001). Swap supports the management of the assets and liabilities of a company or bank and facilitates making investments or taking loans that without their participation would be too expensive or not available at all (Wolańska, 1998). Besides, this contract is a tool that allows exchanging one risk for another. The range of risk factors that can be reduced through swap transactions has been gradually expanding over the past 30 years. The main types of risk that can be changed through the use of swap contracts include the risk of changes in exchange rates, changes in interest rates, changes in share prices, changes in commodity prices, changes in the borrower's creditworthiness or changes in climate conditions (related to, i.e., weather or temperature change) (McDougall, 2001). Taking a specific position in a swap contract can anticipate expected movements in market interest rates (Chisholm, 2009). As a result of a swap transaction, one can secure a position against currency and interest rate risks, make a synthetic diversification of a loan portfolio, reduce the cost of taking out a loan, or change a payment schedule, often so crucial from the point of view of ensuring adequate liquidity for business entities.

The 1970 s and 1980s were a period of virtually no significance for the development of the Polish derivatives market. This also applied to swap transactions. It was not until the political and economic changes in the 1990s that these instruments appeared on the Polish financial market. The following years brought visible changes in this area, and the swap segment developed significantly. The dynamics of the growth of the swap market in Poland against the background of the capital market development after 1989 is so large that its importance in the financial system is significant and is of interest to the Polish central bank. The dynamic development of swap transactions in Poland means that it is justified 
to look for the effects of these changes. Furthermore, this is supported by the fact that it is a relatively new derivative instrument, relatively little attention is paid to such transactions in the literature on the subject, and more and more entities are interested in such transactions. All this means that these processes increase the impact of swap contracts on economic systems. Most swap transactions on the Polish financial market take place on the OTC derivatives market. These transactions are part of both the OTC derivatives market and the OTC interest rate derivatives market, but most of them are made on the currency market. The currency market is an area where supply and demand for currencies of different countries meet (Lutkowski, 1998), a place to exchange one currency for another, meeting the demand for a given currency (Dąbrowski, 2010), as well as a network of connections among all market participants (Taylor, 2000). The currency market is also understood as the entirety of currency exchange transactions together with institutions that help to carry them out (these are mainly commercial banks) and a set of rules according to which currency transactions are concluded, as well as all devices and activities leading to the conclusion of transactions (Zabielski, 2005). The decentralized currency market is global, the geographical location of transaction counterparties is not significant, and trade is smooth and efficient (Dmowski, Prokopowicz, 2010). Although the currency market is a place of spot and forward transactions, such transactions account for a much larger portion of total turnover on it. Among the currency as mentioned earlier derivative financial instruments on the Polish market, the most common are outright forward contracts, FX swap (currency swaps) and currency options. In turn, the use of interest rate derivatives on the Polish derivatives market is based on (Gwizdała, 2013):

- the term structure of individual interest rate derivatives,

- average daily turnover in derivatives markets,

- counterparties of given transactions on the derivatives market.

The main motives for which entities are guided when concluding swap contracts include (Leszczyńska, 2003):

- the ability to manage currency position,

- treating swap contracts as a substitute for loan transactions,

- liquidity management,

- the possibility of increasing the efficiency of undertaken investments or reducing financing costs,

- impact on the type of interest on receivables or liabilities, e.g., from fixed interest rate to variable interest rate,

- the option of securing against interest rate or exchange rate risks,

- an indirect way of using markets that would be inaccessible to a given entity for legal or tax reasons.

Additional benefits that flow from swap transactions on the OTC market also include (Leszczyńska, 2003):

- low transaction costs compared to other derivatives. It is conditioned by the lack of the need to block funds in margins and resignation from premium fees (as in the case of options),

- the ability to choose the risk that an entity wants to take on, by the type and nature of its operations, 
- transaction privacy on the OTC market -only parties to the transaction can know about the contract, which would be impossible if trading on the stock exchange.

\section{MATERIAL AND METHODS}

\section{Analysis of swap transactions on selected financial markets in 2004-2016}

The theoretical considerations in the article were based on a critical analysis of the literature on the subject. In turn, the empirical part of this article was developed using numerical parameters characterizing the studied phenomenon.

The source of empirical data is the results of the turnover study on the foreign exchange market and the OTC derivatives market in Poland. Data on turnover on the currency market and OTC derivatives market in Poland have been presented since 2004, from that moment, for the first time, Poland began to participate in this study to the full extent. Data before 2004 are not fully comparable, because, in the editions of the project from 1998 and 2001, the National Bank of Poland did not carry out a separate statistical survey but based on information obtained from banks in monthly reporting. The NBP forwarded to the Bank for International Settlements only data on turnover in the most developed segments of the domestic currency market and over-the-counter derivatives.

The presented data include transactions in which at least one of the parties was a banking entity or a branch of a credit institution conducting operating activity in Poland, having the status of reporting entity. The data used does not include estimated delays.

The research sample concerning the analysis of turnover on the currency market and the OTC derivatives market in Poland in 2004-2016 was, on average 17 entities, including banks and branches of credit institutions operating in Poland.

In the reports from 2004 and 2007, the currency market and the OTC derivatives market constituted another group of transactions. At that time, the currency market was defined as spot and forward transactions - currency swaps and outright forward contracts. In turn, the OTC derivatives market included the following derivatives: two-currency interest rate swaps (CIRS) and currency options as well as interest rate derivatives - future interest rate contracts (FRA), interest rate swaps (IRS) and interest rate options.

The analysis refers to the currency market, including currency swaps and CIRS transactions, as well as the OTC interest rate derivatives market including interest rate swaps (IRS). The given values are presented in USD million, which results from the standards adopted by BIS. Data on transaction values were forwarded to BIS using prepared reporting forms and detailed guidelines. The National Bank of Poland has checked the correctness of the submitted reports.

\section{Analysis of the currency swaps and currency-interest swaps share, in a turnover on the Polish currency market}

According to the terminology adopted by the Bank for International Settlements, transactions carried out on the currency market include currency swaps and CIRS (Currency Interest Rate Swap) transactions. Table 1 presents the average daily value of foreign exchange swap turnover and CIRS transactions on the Polish currency market, as well as their share in the average daily net turnover on the domestic currency market in the period 2004-2016. 
The analyzed data show that currency swaps constitute the main share in all transactions performed on the currency market. In the period from 2004 to 2016, their average percentage share in the currency market was around $64,64 \%$, and their average daily value was USD 5177 million.

The large share of currency swaps relative to the entire currency market is primarily due to the various possibilities of their use. According to the National Bank of Poland, foreign banks use currency swaps, i.e., to manage liquidity in PLN and to finance their involvement on the market of treasury bonds denominated in PLN. In turn, domestic banks use foreign exchange swap transactions to limit the currency risk related to housing loans denominated in foreign currencies in markets. In addition to banking institutions, foreign exchange swaps also use other financial institutions to speculate on changes in interest rates, as well as in strategies for opening currency positions.

Considering currency-interest rate swap transactions, it should be noted that they did not even exceed $2 \%$ in all transactions on the Polish currency market. In the discussed period, their average daily value is USD 87 million.

Table 1. Average daily value of swap and CIRS transactions, as well as their share in the total sum of all daily transactions on the Polish currency market in the period 2004-2016 (in USD million)

\begin{tabular}{|c|c|c|c|c|c|c|}
\hline Years & 2004 & 2007 & 2010 & 2013 & 2016 & \multirow{2}{*}{$\overline{\boldsymbol{x}}$} \\
\hline Currency market & $6534 *$ & 9224* & 7848 & 7564 & 9116 & \\
\hline Foreign exchange swaps & 4095 & 5881 & 5368 & 4581 & 5958 & 5176.6 \\
\hline CIRS transactions & 3 & 68 & 79 & 125 & 160 & 87 \\
\hline Other & 2442 & 2932 & 2401 & 2858 & 2998 & 2726.2 \\
\hline Share of currency swaps in the currency market (\%) & 62.67 & 66.22 & 68.4 & 60.56 & 65.36 & 64.64 \\
\hline CIRS share in the currency market (\%) & 0.05 & 0.77 & 1.01 & 1.65 & 1.76 & 1.05 \\
\hline
\end{tabular}

* currency derivatives (CIRS contracts and currency options) + currency market (cash, outright-forward transactions and currency swaps) - data provided following the new definition of the currency market, in force since 2010. Source: National Bank of Poland $(2004,2007,2010,2013,2016)$. The results of the turnover survey on the currency market and OTC derivatives market in Poland, Warsaw.

The cited data shows that in the period from 2004 to 2016, there was no significant increase in the daily value of swap transactions performed on the Polish currency market, as shown in Figure 1. In turn, analyzing CIRS transactions, one can see an apparent increase in their value in one day (although their total value is still much lower than currency swaps). The reason for this could be a significant increase in the number of transactions concluded by domestic banks to hedge currency risk and interest rate risk resulting from a mismatch in the structure of loans granted and deposits accepted. A detailed analysis of the value of CIRS transactions is presented in Figure 2.

\section{Analysis of the IRS transactions share in a turnover on the Polish interest rate OTC derivatives market}

According to the terminology adopted by the Bank for International Settlements, transactions carried out on the interest rate OTC derivative market include, i.e., interest rate swaps or IRS (Interest Rate Swap). Their average daily value in the period from 2004 to 2016 was USD 799,2 million, while their average share in the entire Polish OTC interest rate derivatives market was around 40,55\%. FRA (Forward Rate Agreement) transactions, 


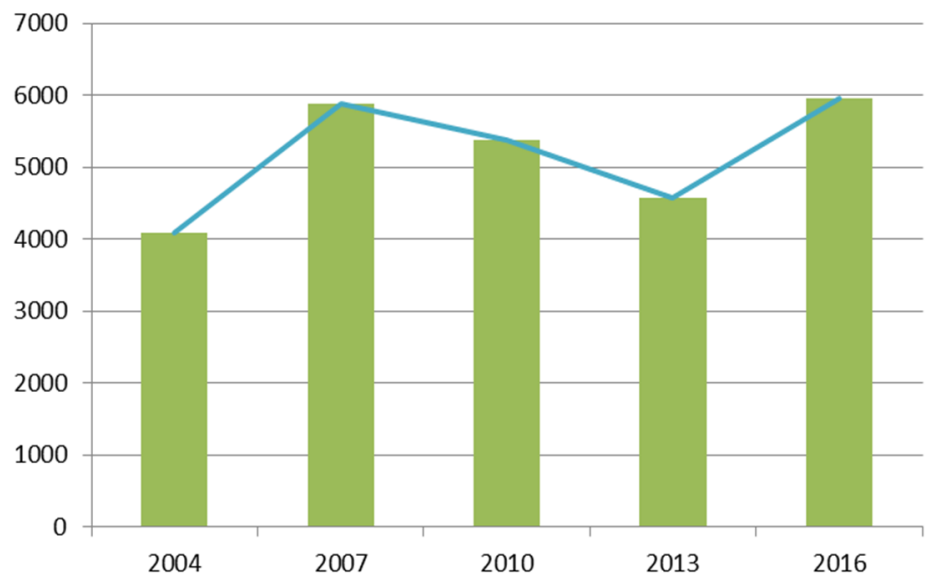

Figure 1. Average daily value of swap transactions on the Polish currency market in the period 2004-2016 (in USD million)

Source: National Bank of Poland (2004, 2007, 2010, 2013, 2016). The results of the turnover survey on the currency market and OTC derivatives market in Poland, Warsaw.

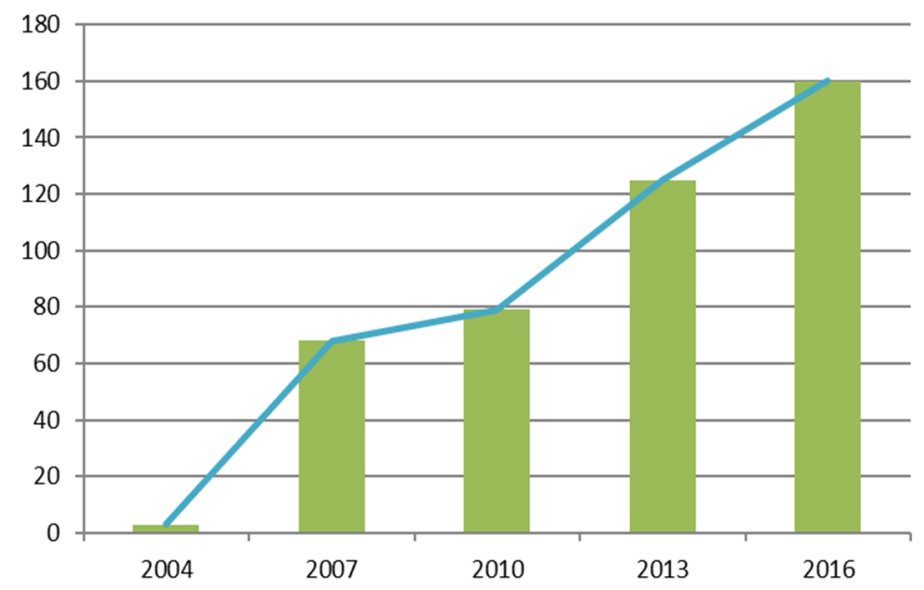

Figure 2. Average daily value of CIRS transactions on the Polish currency market in the period 2004-2016 (in USD million)

Source: National Bank of Poland $(2004,2007,2010,2013,2016)$. The results of the turnover survey on the currency market and OTC derivatives market in Poland, Warsaw.

which are the effective interest rate for the future period already known on the day of the transaction, were used much more frequently. Their average share in this market was about 59,19\%, and the average value was around USD 1154,4 million. Detailed information is presented in Table 2 .

According to the data from Table 2, it can be stated that in the period from 2004 to 2016, the daily values of IRS transactions performed were variable and did not show a steady increase over the years, as did their share in all transactions on the derivatives market. Increases and decreases in IRS transactions may have depended on their use by banks 
both for speculative purposes, but also to limit the interest rate risk arising from the balance sheet position (major debt securities). Figure 3 shows the fluctuations in the daily values of IRS transactions in the period from 2004 to 2016.

Table 2. Average daily value of IRS transactions and their share in the total sum of all daily transactions on the Polish derivatives market in the period 2004-2016 (in USD million)

\begin{tabular}{|l|l|l|l|l|l|l|}
\hline \multicolumn{1}{|c|}{ Years } & $\mathbf{2 0 0 4}$ & $\mathbf{2 0 0 7}$ & $\mathbf{2 0 1 0}$ & $\mathbf{2 0 1 3}$ & $\mathbf{2 0 1 6}$ & \multirow{2}{*}{$\overline{\boldsymbol{x}}$} \\
\cline { 1 - 8 } \multicolumn{1}{|c|}{ Currency market } & $958^{*}$ & $2681^{*}$ & 1561 & 3038 & 1558 & \\
\hline IRS transactions * & 267 & 1240 & 786 & 992 & 711 & 799.2 \\
\hline FRA transactions & 691 & 1435 & 775 & 2035 & 836 & 1154.4 \\
\hline Other & 0 & 6 & 0 & 11 & 11 & 5.6 \\
\hline IRS share in the interest rate derivatives market (in \%) & 27.87 & 46.25 & 50.35 & 32.65 & 45.64 & 40.55 \\
\hline FRA share in the interest rate derivatives market (in \%) & 72.13 & 53.52 & 49.65 & 66.98 & 53.66 & 59.19 \\
\hline
\end{tabular}

* including OIS transactions (Overnight Index Swap).

Source: National Bank of Poland (2004, 2007, 2010, 2013, 2016). The results of the turnover survey on the currency market and OTC derivatives market in Poland, Warsaw.

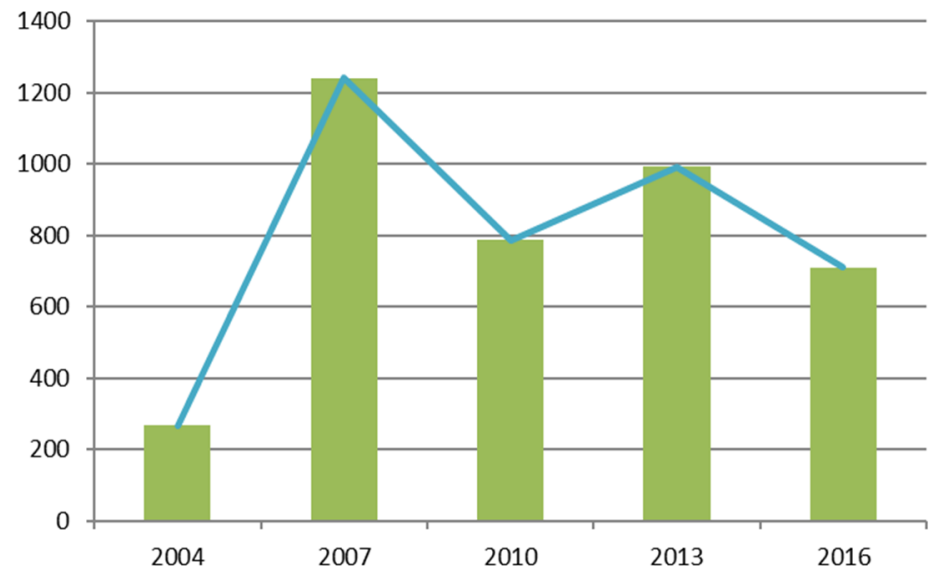

Figure 3. Average daily IRS transaction values and their fluctuations on the Polish OTC interest rate derivatives market in 2004-2016 (in USD million)

Source: National Bank of Poland $(2004,2007,2010,2013,2016)$. The results of the turnover survey on the currency market and OTC derivatives market in Poland, Warsaw.

\section{Impact assessment of the swap transactions on the development of the Polish currency market and OTC derivatives market}

Currently, the Polish swap contract market is developing dynamically, including first- and second-generation swaps. It functions just like the international contract market, meeting the principles of the OTC (Over the Counter) market. One of its main advantages is flexibility and the ability to conclude transactions directly between market participants. In addition, the price of the financial instrument and its specification is determined each time between the parties to the transaction. Many companies see the swap contracts as the opportunity to manage financial risk actively.

Searching for access to cheaper capital is a challenge for most Polish entrepreneurs. Swap transactions allow freely manage assets and liabilities. Among Polish market partic- 
ipants, the level of knowledge about transaction risk and how to secure against it is gradually increasing, which increases the interest in this type of derivatives. The main participants using swap contracts on the Polish currency market are banks, brokerage companies, and entrepreneurs (but to a lesser extent compared to other participants).

Currently, the most liquid instrument on the Polish currency market is currency swaps. Polish banking institutions that use swap contracts manage currency positions and their liquidity. A large part of transactions is also concluded between Polish and foreign banks (Leszczyńska, 2003). Foreign exchange swaps are used by foreign entities, i.e., to finance their positions in securities denominated in PLN (foreign institutions prefer systematic renewal of short-term FX swap transactions). Interest in CIRS contracts has also been growing since 1999. Almost all these transactions carried out by domestic banks in April 2016 were reconciled with other banks, mainly foreign ones or with non-financial public sector entities. The use of this type of derivatives enables securing against interest rate risk. Many of the second-generation swap transactions, which include, i.e., callable swap, puttable swap, floored swap, capped swap, and callared swap does not yet have a Polish name. The use of this group of swap contracts is still relatively low in Poland, although there is some interest.

The versatility of swap instruments contributes to the development of the Polish currency market and OTC derivatives market, as the diversity of use and flexibility of swaps is appreciated by subsequent market participants. The motivation that supports the use of swap transactions by Polish business entities is either the desire to gain a competitive advantage or a commercial need. Some business activities of companies in the financial industry generate exposure to risk, both in currency and interest rates. Swaps minimize this risk.

\section{CONCLUSIONS}

Critical analysis of the literature indicates that we are currently observing the dynamic development of both first and more often second-generation swap contracts. The possibilities of various swap applications depend on the existence of different types and their flexibility, which results from the operation of OTC transactions. Each of the parties to the transaction may affect the terms of the contract and adapt them to their needs. They can be used in many ways, including in hedging, risk diversification, and cost optimization.

From the empirical studies carried out and described above, the following conclusions were made:

- In the case of currency markets, in the period from 2004 to 2016, the average percentage share of currency swaps was about $64,64 \%$; therefore, it was the most frequently used instrument.

- Despite the significant share in the currency swap market, they do not show an upward trend during the period considered. Their value varies over the years.

- Figures for CIRS transactions indicate that although these transactions represent only a $2 \%$ share in the entire currency market, a steady increase in the value of these transactions is observed from 2004 to 2016.

- In the case of OTC interest rate markets in the period from 2004 to 2016, the average percentage share of IRS transactions was around $40,55 \%$, so it was not the most used instrument. FRA transactions were much more often used, their average share in this market was about $59,19 \%$. 
- In the period from 2004 to 2016, the daily values of IRS transactions performed were variable and did not show steady growth over the years, as did their share in all transactions on the derivatives market.

Therefore, it cannot be unequivocally confirmed that swaps, due to their universality and design, are the most frequently used instrument of the Polish currency market and the OTC interest rate derivatives market. This is because, although, on the currency market, the main share in transactions was achieved by currency swaps, in the case of the OTC interest rate market, interest rate swap (IRS) transactions no longer record the largest share.

The issue of swap contracts, according to the authors of the thesis, is the subject of limited interest in the Polish research literature, and this article was to be a response to the need to systematize knowledge about these instruments and a synthetic presentation of their development. To conclude the considerations made in this article, it should be noted that the conducted research shows that only certain types of swaps find recognition among investors and are instruments relatively often used in financial markets. Future research should focus on comparing the swap contract market in Poland with other EU countries. Such research would give an opportunity for a broader comparative assessment of the swap market and indicate the most desirable directions for its further development in Poland.

\section{REFERENCES}

Chisholm, A.M. (2009). An Introduction to International Capital Markets: Products, Strategies, Participants. Wiley Finance.

Czekaj, J. (2008). Rynki, instrumenty i instytucje finansowe. Warszawa: PWN.

Dąbrowski, P. (2010). Rynek finansowy. Katowice: Wydawnictwo Uniwersytetu Ekonomicznego w Katowicach.

Dmowski, A., \& Prokopowicz, D. (2010). Rynki finansowe. Warszawa: Difin.

Gwizdała, J. (2013). Instrumenty pochodne w ograniczaniu ryzyka stopy procentowej w bankach komercyjnych. Finanse, Rynki Finansowe, Ubezpieczenia, 60, 442-443.

Hull, J. (1997). Kontrakty terminowe i opcje. Wprowadzenie. WIG PRESS, Warszawa.

Jajuga, K. (2009). Derivative instruments. Warsaw: Polish Financial Supervision Authority.

Kolb, R. (1997). Wszystko o instrumentach pochodnych. Warszawa: WIG Press.

Kukurba, M. (2016). Walutowe i procentowe transakcje zamiany - podstawy mechanizmu działania. Kwartalnik Kolegium Ekonomiczno-Społecznego Studia i Prace, 2, 25-26.

Leszczyńska, E. (2003). Rynek kontraktów SWAP w Polsce. Warszawa: Narodowy Bank Polski.

Lutkowski, K. (1998). Międzynarodowy system walutowy. Warszawa: Poltext.

Malinowski, A. (2011). Zastosowanie kontraktów swap w Polsce. Zeszyty Naukowe Uniwersytetu Przyrodniczo-Humanistycznego w Siedlcach-Administracja i Zarzqdzanie, 88, 127-128.

Martinkute-Kaulienè, R. (2015). Risk Factors in Derivatives Markets. Entrepreneurial Business and Economics Review, 2(4), 71-83.

Marynarski, S. (1999). Rynek opcji. Kraków: Wydawnictwo Uniwersytetu Ekonomicznego w Krakowie. McDougall, A. (2001). Swapy. Kraków: Oficyna Wydawnicza ABC.

NBP (2018). Derivative instrument. Narodowy Bank Polski. Retrieved from: https://www.nbportal.pl/slownik/pozycje-slownika/instrument-pochodny (02.04.2018). 
NBP (2004). The results of the turnover survey in April 2004 on the currency market and OTC derivatives market in Poland. Warsaw: National Bank of Poland.

NBP (2007). The results of the turnover survey in April 2007 on the currency market and OTC derivatives market in Poland. Warsaw: National Bank of Poland.

NBP (2010). The results of the turnover survey in April 2010 on the currency market and OTC derivatives market in Poland. Warsaw: National Bank of Poland.

NBP (2013). The results of the turnover survey in April 2013 on the currency market and OTC derivatives market in Poland: National Bank of Poland. Warsaw.

NBP (2016). The results of the turnover survey in April 2016 on the currency market and OTC derivatives market in Poland. Warsaw: National Bank of Poland.

Rule, D. (2011). The credit derivatives market: its development and possible implications for financial stability. Bank of England Financial Stability Review.

Taylor, F. (2000). Rynki i opcje walutowe. Kraków: Oficyna Wydawnicza ABC.

Trader's Area. (2018). The most important derivatives in the world. Retrieved from: http://tradersarea.pl/najwazniejsze-instrumenty-pochodne-na-swiecie/ (02.04.2018).

Tymuła, I. (2000). Swapy finansowe. Warszawa: Biblioteka Menedżera i Bankowca.

Wolańska, A. (1998). Transakcje SWAP. Rynek Kapitałowy, 3.

Zabielski, K. (2005). Finanse międzynarodowe. Warszawa: PWN.

Zając, J. (2000). Polski rynek walutowy w praktyce. Warszawa: Wydawnictwo K.E. Liber. 


\section{Authors}

The contribution share of authors is equal and amounted to $50 \%$ each of them.

\section{Robert W. Włodarczyk}

Associate professor at the Department of Theory of Economics, Cracow University of Economics. Master's degree in economics from Cracow University of Economics in 1999; PhD in economics from Cracow University of Economics in 2006; Dr hab. in economics from Cracow University of Economics in 2014.

Correspondence to: Dr hab. Robert W. Włodarczyk, PhD, Cracow University of Economics, College of Economics, Finance and Law, Department of Theory of Economics ul. Rakowicka 27, 31510 Kraków, Poland, e-mail: robert.wlodarczyk@uek.krakow.pl

ORCID (1) http://orcid.org/0000-0001-7610-6504

\section{Magdalena Sikorska}

PhD student at Cracow University of Economics, Colelge of Economis, Finance and Law. Master's degree in economics from Cracow University of Economics in 2018; Engineer's degree at Silesian University of Technology in 2018.

Correspondence to: Mgr Magdalena Sikorska, Cracow University of Economics, College of Economics, Finance and Law, Department of Theory of Economics ul. Rakowicka 27, 31-510 Kraków, Poland, e-mail: magdalena.sikoorska@wp.pl

ORCID (1) http://orcid.org/0000-0001-9630-2959

\section{Copyright and License}

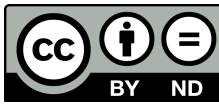

This article is published under the terms of the Creative Commons

Attribution - NoDerivs (CC BY-ND 4.0) License

http://creativecommons.org/licenses/by-nd/4.0/

Published by the Centre for Strategic and International Entrepreneurship - Krakow, Poland

The journal is co-financed in the years $2019-2020$ by the Ministry of Science and Higher Education of the Republic of Poland in the framework of ministerial programme "Support for Scientific Journals" (WCN) on the basis of contract no. 238/WCN/2019/1 concluded on 15 August 2019. 